\title{
PENDEKATAN KOMPREHENSIF DALAM PEMBELAJARAN PENDIDIKAN PANCASILA DAN KEWARGANEGARAAN
}

\author{
Joko Wahono ${ }^{1}$, Intan Kusumawati ${ }^{2}$, Ahmad Nasir Ari Bowo ${ }^{3}$ \\ ${ }^{1,2,3}$ Pendidikan Pancasila dan Kewarganegaraan, Universitas Cokroaminoto Yogyakarta \\ Jl. Perintis Kemerdekaan, Gambiran, Umbulharjo, Kota Yogyakarta 55161 \\ ${ }^{1}$ Email: jokowahono@ucy.ac.id \\ ${ }^{2}$ Email: intankusumawati@ucy.ac.id \\ ${ }^{3}$ Email: ahmadnasiraribowo@ucy.ac.id
}

\begin{abstract}
ABSTRAK
Nilai-nilai karakter bangsa menjadi masalah yang penting apabila masih ditemukannya sikap ataupun perilaku yang tidak terpuji yang dilakukan seseorang dalam kehidupan kesehariannya yang berakibat menganggu kehidupan bermasyarakat, berbangsa dan bernegara. Perkembangan zaman dan teknologi yang begitu pesatnya tanpa diiringi karakter atau perilaku yang baik akan menjadi masalah. Sikap dan perilaku seorang pelajar yang sering kita jumpai seperti perkelahian antar pelajar, tawuran, penyalahgunaan narkoba, mabuk-mabukan serta pergaulan bebas akan berdampak negatif untuk perkembangan karakter pelajar. Diperlukan sinergi antara orang tua, guru dan masyarakat dalam pembentukan dan pengembangan karakter. Di dalam Pendidikan Pancasila dan Kewarganegaraan bertujuan menjadikan seseorang menjadi warga negara baik, berkarakter serta menjadikan manusia yang demokratis dan memiliki nilai-nilai pancasila. Pembentukan karakter siswa ataupun pelajar tidak bisa diperoleh secara instan, tentunya melalui proses sesuai dengan tahapan perkembangan seseorang. Membentuk karakter membutuhkan waktu yang terus menerus yang pada akhirnya menjadi sebuah karakter yang diharapkan. Pendekatan komprehenshif akan dapat mengembangkan dan menjadikan seseorang mempunyai karakter yang baik. Pembentukan dan pengembangan karakter dengan pendekatan komprehenshif yaitu melalui inkulkasi atau penanaman nilai, pemberian suri tauladan, fasilitasi serta pengembangan keterampilan (soft skill).

Kata Kunci: Komprehenshif, Pendidikan Pancasila dan Kewarganegaraan.
\end{abstract}

\begin{abstract}
The values of the national character become an important problem if there is still a disgraceful attitude or behavior carried out by a person in his daily life which results in disrupting the life of the community, nation and state. The rapid development of times and technology without good character or behavior will be a problem. The attitudes and behavior of a student that we often encounter, such as fights between students, brawls, drug abuse, drinking and promiscuity will have a negative impact on the development of student character. Synergy is needed between parents, teachers and the community in character building and development. In Pancasila and Citizenship Education aims to make someone a good citizen, have character and make a human being who is democratic and has Pancasila values. The formation of student or student character cannot be obtained instantly, of course, through a process according to a person's stages of development. Forming a character takes a continuous amount of time which eventually becomes an expected character. A comprehensive approach will be able to develop and make someone have good character. The formation and development of character with a comprehensive approach, namely through inculcation or planting of values, giving role models, facilitation and the development of skills (soft skill).
\end{abstract}

Keywords: Comprehensive, Pancasila and civic education. 


\section{PENDAHULUAN}

Pendidikan merupakan suatu usaha pencapaian proses menuju ke arah yang lebih baik dan bermartabat. Sebuah negara yang berkarakter akan bisa menjadi bekal dalam mencapaian tujuan negaranya. Sebaliknya negara yang tidak mempunyai pembangunan karakter yang baik akan menjadi negara yang akan mengalami kemerosotan dalam berbagai hal. Perkembangan teknologi menjadi faktor yang paling berpengaruh dalam sebuah pendidikan. Landasan filosofi dalam pengembangan karakter menjadi arah bagi pengembangan karakter itu sendiri dalam proses pendidikan (Kusumawati, 2016). Pendidikan karakter merupakan usaha sadar mewujudkan pribadi seorang memiliki nilai kebajikan sebagai individu dan masyarakat (Lickona \& Matters, 2012). Pendidikan karakter mempengaruhi kepribadian seseorang dan perilaku kebajikan dalam menjalani kehidupan yang lebih baik (Flanagan et al., 1993). Pendidikan karakter membawa tujuan menanamkan sesuatu yang baik dan terpuji (Flanagan et al., 1993). Pendidikan karakter bertujuan untuk mengembangkan potensi seseorang melalui usaha sadar dan terencana dalam proses pembelajaran untuk mewujudkan suasana belajar serta suatu proses pembelajaran supaya pelajar secara aktif mengembangkan potensi dirinya dalam kekuatan spiritual keagamaan, pengendalian diri, kepribadian, kecerdasan, akhlak mulia, serta keterampilan yang diperlukan dirinya, masyarakat, bangsa dan negara (Sisdiknas, 2003). Warga Negara yang baik apabila diwujudkan memiliki karakter dan kebajikan, adanya keterkaitan antara kebaikan dan kebajikan (Arthur \& Harrison, 2012). Warga Negara yang baik taat dalam peraturan pemerintah (B.-Y. Sim \& Low, 2012).

Tantangan pendidikan sekarang bagaimana seorang guru dapat mendidik dan menyemangati pelajar agar dapat mengembangkan potensi dirinya dan ketrampilannya dengan karakter sesuai dengan kepribadian bangsa Indonesia dengan pancasila sebagai pedoman keseharian. Di dalam proses pembelajaran seorang guru dituntut agar dapat mempersiapkan perangkat mengajar di kelas supaya dapat mencapai tujuan pembelajaran. Media pembelajaran menjadi hal terpenting dalam proses pembelajaran supaya pelajar atau siswa antusias dan serius serta sungguh-sungguh dalam mempelajari pengetahuan dan ketrampilan yang disampaikan guru.

Guru PPKn di sekolah selama ini telah melakukan proses pembelajaran dengan baik dan terencana. Namun dalam membentukan dan pengembangan karakter siswa memang dituntut penanganan serius dan diperlukan sinergi antara guru, orang tua dan masyarakat. Pemberian indoktrinasi dalam pembentukan karakter saja tidaklah cukup, namun yang terpenting adalah pemberian suri tauladan yang baik. Pembentukan pribadi seseorang agar 
mempunyai sikap mandiri dalam pembuatan keputusan moral mutlak diperlukan (Zuchdi, 2004). Ketika seorang pelajar masih anak tentunya dalam pendidikan masih meniru siapa saja yang menjadi suri teladannya. Melalui pendekatan konstruktivis seorang anak diberikan kesempatan untuk belajar pada lingkungan sekitar kehidupannya dengan membangun pemahaman moral melalui interaksi sosial yang dialamainya (Kusumawati \& Zuchdi, 2019).

\section{METODE PENELITIAN}

Penelitian ini menggunakan pendekatan kualitatif yang akan mengungkapkan bagaimana pelaksanaan pendekatan komprehenshif dalam pembelajaran Pendidikan Pancasila dan Kewarganegaraan di SMA wilayah Daerah Istimewa Yogyakarta dapat membentuk karakter seseorang menjadi seorang warga negara yang baik dan memiliki karakter pancasila. Prosedur dalam penelitian ini adalah pertama melakukan tahapan perencanaan dengan cara menyusun pedoman wawancara dan pembuatan instrument penelitian dengan menggunakan google formulir.

Selanjutnya pelaksanaan tindakan dengan bertemu dengan guru PPKn dan melakukan wawancara serta meminta guru mengisi google formulir yang telah dikirimkan melalui email ataupun whatsapp. Setelah data penelitian telah cukup dan dapat dipilahpilah. Data yang sudah didapatkan kemudian dianalisis dan disimpulkan. Subjek dalam penelitian ini adalah 5 sekolah yang ada di wilayah Daerah Istimewa Yogyakarta. Kelima sekolah tersebut adalah Sekolah yang diteliti terdiri 5 sekolah yang terdiri dari SMA N 2 Sleman, SMA N 1 Sentolo Kulon Progo, SMA Negeri Patuk Gunung Kidul, SMA N 1 Banguntapan Bantul dan SMA Muhammadiyah 2 Yogyakarta.

\section{HASIL DAN PEMBAHASAN}

Pendekatan komprehenshif adalah suatu pendekatan yang dilakukan secara menyeluruh agar tujuan pembelajaran tercapai yang meliputi orientasi, eksplorasi, pendalaman dan penyimpulan (Nucci \& Narváez, 2014). Tujuan Pendidikan Pancasila dan Kewarganegaraan adalah menjadikan seseorang menjadi warganegara yang baik, taat, patuh, memiliki sikap patriotik dan mempunyai nilai-nilai kebangsaan dan memiliki jiwa dan karakter pancasila yang mandiri, kreatif dan inovatif. Pembentukan karakter melalui usaha sadar dan terencana agar dapat mengembangkan potensi kepribadian yang berkarakter (Lickona, 1991). Istilah komprehensif yaitu pendidikan yang didalamnya terkandung nilai-nilai mencakup beberapa hal yaitu meliputi semua permasalahan yang 
berhubungan dengan nilai-nilai yang pribadi, etika dan norma secara umum. Dalam metode pendidikan nilai yang digunakan juga harus komprehensif. Termasuk penanaman nilai (inkulkasi), pemberian keteladanan, fasilitasi serta pengembangan keterampilan (soft skill). Pendidikan nilai dapat dilakukan dengan metode langsung yaitu dengan menentukan perilaku yang dinilai baik sebagai indoktrinasi berbagai ajaran dengan cara mendiskusikan menghafalkan ataupun mengucapkan. Pendidikan nilai juga dapat dilakukan dengan metode yang tidak langsung yaitu dengan menciptakan situasi yang memungkinkan perilaku yang baik dapat dipraktekkan secara langsung oleh seseorang dalam kehidupannya yang dialaminya.

Pendidikan Pancasila dan Kewarganegaraan yang dilakukan di sekolah merupakan metode pendidikan nilai secara langsung, dan terkadang terdapat indoktrinasi secara tidak langsung. Dalam pendidikan karakter pentingnya penguatan karakter (Berkowitz \& Bier, 2004). Keputusan yang diambil untuk perilaku harus siap untu dipertanggungjawabkan secara sadar (Sumardjoko, 2003). Etika kebajikan dan etika kepedulian diharapkan dalam pendidikan karakter atau pendidikan nilai (Noddings, 2002). Dalam kenyataannya di kelas seorang pelajar bisa menyerap bahkan terkadang hapal di luar kepala apa yang telah diajarkan dan disampaikan guru namun terkadang belum secara langsung diamalkan dalam kehidupan sehari-hari, apabila diterapkan juga dikarenakan karena pengawasan bukan karena kesadaran yang dimilikinya. Nilai-nilai moral yang dilakukan seharusnya bersifat suka rela (voluntary action) tanpa adanya paksaan dari pihak manapun dan berubah menjadi nilai hukum yang dalam segala aspeknya memerlukan pranata hukum (Zuchdi, 2004). Pembentukan pendidikan kewarganegaraan sebagai mata pelajaran wajib telah dilakukan dibarengi kebijakan pemerintah untuk 'menggenjot pendidikan berkarakter. Identifikasi memiliki peran penting untuk dimainkan dalam membantu membentuk dan memperkuat karakter dasar (Berkowitz \& Bier, 2004). Pendidikan nilai hendaknya terjadi secara keseluruhan proses pendidikan di sekolah. Tidak hanya dalam proses pembelajaran dikelas tetapi juga dalam kegiatan ekstrakurikuler, dalam proses bimbingan dan penyuluhan dan semua aspek kehidupan. Pendidikan nilai hendaknya juga melalui kehidupan masyarakat. Selain dari keluarga yaitu orangtua melainkan juga dari organisasiorganisasi dimasyarakat atau lembaga keagamaan seperti Taman Pendidikan Al-Quran (TPA), dalam penanaman pendidikan nilai guna memperbaiki karakter dan moral generasi bangsa (Zuchdi, 2004).

Pendidikan nilai atau pendidikan karakter seharusnya dapat menumbuhkan kemandirian siswa atau pelajar, karena di dalamnya mengajarkan tentang arti kedisiplinan 
dan kemandirian agar dapat bisa menyelesaikan permasalahan yang dihadapi dalam kehidupan di keluarga, sekolah ataupun masyarakat. Siswa ataupun pelajar diharapkan dapat menyesuaikan diri dengan lingkungan serta dapat mengorbankan nilai-nilai yang positif yang harus dipertahankan. Dalam kehidupan masyarakat yang keras harus dapat memiliki kemampuan untuk bertahan dan dapat mengatasi semua persoalan dan hambatan yang dialaminya. Siswa atau pelajar harus memiliki motivasi yang besar dan semangat yang tinggi dalam menghadapi kehidupan masyarakat yang keras dan terkadang tidak manusiawi dengan memiliki sikap mandiri dan memiliki nilai moral yang baik.

Dalam aspek kognitif siswa atau pelajar dapat menentukan pilihan moral secara tepat dan aspek afektif siswa atau pelajar dapat menanjamkan kepekaan hati nuraninya dengan memiliki dorongan untuk melakukan tindakan yang baik atau bermoral. Sikap dan perilaku siswa dalam menjalankan ibadah dan kepercayaan masing-masing dapat menumbuhkan sikap religi atau ketakwaan kepada Tuhan YME dengan menjalankan semua perintahnya dan menjauhi semua larangannya merupakan pondasi yang utama dalam dirinya menjadi pribadi yang baik dan bermoral. Dalam kehidupan sosial dan masyarakat contohnya sikap dan perilaku seorang siswa atau pelajar harus dapat mencerminkan pribadi yang baik dan bermoral melalui semua ucapan, pikiran serta tindakan dalam kehidupannya keseharian di tengah-tengah masyarakaat. Dapat menolong dan memiliki sikap sosial serta solidaritas yang tinggi sangatlah diharapkan dalam menunjang nilai-nilai moral yang dilakukannya sehingga terjadi persemaian benih-benih moralitas dalam kehidupan masyarakat (Zuchdi, 2004).

Pendidikan moral merupakan pengalaman manusia dalam kehidupannya (Flanagan et al., 1993). Pendidikan karakter atau pendidikan nilai yang diberikan secara indoktrinasi tidak cukup oleh karena itu perlunya ada pendekatan komprehenshif agar siswa atau pelajar dalam mengembangkan potensi dan ketrampilannya secara maksimal dan terarah. Pendidikan nilai dan moral memungkinkan siswa atau pelajar mampu mengambil keputusan dengan bijaksana dan secara mandiri dalam memilih nilai-nilai yang sangat bertentangan yang terjadi dalam kehidupan keseharian yang dialaminya. Pendekatan komprehensif adalah baik diterapkan dalam pembelajaran PPKn di sekolah agar siswa atau pelajar dapat menerapkannya dalam kehidupannya baik di sekolah, keluarga atau masyarakat. 
Pendekatan komprehenship dalam pembelajaran Pendidikan Pancasila dan

\section{Kewarganegaraan.}

\section{Penanaman nilai (inkulkasi nilai)}

Dalam pembelajaran di kelas ataupun di luar kelas hendaknya seorang guru dapat menanamkan nilai-nilai moral dan tindakan yang bermoral. Penanaman nilai bisa dilakukan dengan pembelajaran meliputi pengetahuan dan ketrampilan. Penanaman nilai-nilai tradisional dari orang dewasa yang meneruh perhatian kepada mereka yaitu orangtua, guru, dan masyarakat. Dalam penanaman nilai memiliki ciri sebagai berikut: (a) mengomunikasikan kepercayaan disertai alasan yang mendasarinya; (b) memperlakukan orang lain secara adil; (c) menghargai pandangan orang lain; (d) mengemukakan keragu-raguan atau perasaan tidak percaya disertai dengan alasan; dan dengan rasa hormat; (e) tidak sepenuhnya mengontrol lingkungan untuk meningkatkan kemungkinan penyampaian nilai-nilai yang dikehendaki dan mencegah kemungkinan penyampaian nilai-nilai yang tidak dikendendaki; (f) menciptakan pengalaman sosial dan emosional mengenai nilai-nilai yang dikehendaki secara tidak ekstrem; (g) membuat aturan, memberikan penghargaan, dan memberikan konsekuensi disertai alasan; (h) tetap membuka komunikasi dengan pihak yang tidak setuju; dan (i) memberikan kebebasan bagi adanya perilaku yang berbeda-beda, apabila sampai pada tingkat yang tidak dapat diterima, diarahkan untuk memberikan kemungkinan berubah (Zuchdi, 2004).

\section{Pemberian keteladanan}

Dalam pendidikan nilai dan spiritualitas, pemodelan atau pemberian suri tauladan sangatlah diperlukan dan merupakan strategi yang digunakan dalam menyiapkan generasi yang bermoral dan mandiri. Guru, orang tua ataupun orang dewasa harus berperan sebagai model yang baik bagi siswa-siswanya atau anak-anaknya. Siswa atau pelajar memerlukan teladan dari orang dewasa mengenai integritas kepribadian dan kebahagiaan hidup. Orang dewasa seharusnya memberikan teladan seperti tidak merokok, tidak korupsi, tidak melakukan kekerasan, tidak berbuat curang serta mengajarkan tentang arti kebaikan dan kebajikan. Memberikan contoh untuk hidup hemat, cermat, dermawan, jujur, adil, saling menyayangi sesama makhluk Allah SWT. Siswa, pelajar atau anak-anak harus meneladani orang yang terkenal dan memiliki akhlaq yang mulia, misalnya Nabi Muhammad saw. Cara guru menghadapi masalah dan persoalan yang dihadapi secara baik, adil dan bijak akan menjadi teladan bagi siswa/pelajar. Mengkritik dan memberikan saran kepada orang lain secara hati-hati dan 
santun juga menjadi suri tauladan yang baik dan dapat ditiru oleh siswa/ pelajar di sekolah. Guru, orang tua, ataupun orang dewasa perlu kehati-hatian dan berucap, bertutur kata atau bersikap/bertindak di depan anak/siswa, supaya tidak menanamkan nilai-nilai negatif dalam diri sanubari anak ataupun siswa (Zuchdi, 2004).

Guru dan orangtua perlu memiliki ketrampilan asertif dan ketrampilan menyimak. Kedua ketrampilan ini sangat diperlukan untuk menjalin hubungan antarpribadi dan antar kelompok. Oleh karena itu, perlu dijadikan contoh bagi anak-anak ataupun siswa/ pelajar. Ketrampilan asertif adalah ketrampilan mengemukakan pendapat secara terbuka, dengan cara-cara tidak melukai perasaan orang lain. Ketrampilan menyimak adalah ketrampilan mendengarkan dengan penuh pemahaman dan secara kritis (Zuchdi, 2004).

\section{Fasilitasi}

Dalam keseharian diperlukan fasilitasi pembuatan keputusan moral secara bertanggungjawab dalam ketrampilan-ketrampilan hidup yang lain. Fasilitasi melatih siswa atau pelajar mengatasi masalah-masalah yang dihadapi dalam kehidupan kesehariannya. Bagian yang terpenting dari fasilitasi adalah pemberian kesempatan kepada siswa atau pelajar. Kegiatan fasilitasi dapat memberikan hubungan baik antara guru dan siswa. Apabila guru mendengarkan siswa atau pelajar dengan sungguhsungguh dan sepenuh hati maka siswa atau pelajar akan melakukan hal sama yaitu mendengarkan guru dengan baik dan sungguh-sungguh. Siswa atau pelajar akan merasa dihargai dan diperhatikan dengan sepenuhnya oleh guru mengenai apa yang disampaikan baik pendapat atau pandangannya (Zuchdi, 2004).

Kegiatan fasilitasi menolong siswa atau pelajar memperjelas pemahaman. Kegiatan tersebut memberikan kesempatan untuk menyusun pendapat, mengingatkan kembali hal-hal yang perlu disimak, dan memperjelas hal-hal yang masih diragukan. Kegiatan fasilitasi menolong siswa atau pelajar yang sudah menerima suatu nilai, tetapi belum mengamalkannya secara konsisten, meningkat dari pemahaman secara intelektual ke komitmen untuk bertindak. Tindakan moral memerlukan tidak hanya pengetahuan, tetapi perasaan, maksud, dan kemauan. Kegiatan fasilitasi menolong siswa atau pelajar berpikir lebih jauh tentang nilai yang dipelajari, menemukan wawasan sendiri, belajar dari teman-temannya yang telah menerima nilai-nilai (values) yang diajarkan, dan akhirnya menyadarkan kebaikan dan kebajikan hal-hal yang disampaikan oleh guru. Kegiatan fasilitasi menyebabkan guru lebih dapat memahami bagaimana pola pikiran dan perasaan dari siswa atau pelajar. Kegiatan fasilitasi akan 
dapat memotivasi siswa atau pelajar dalam menghubungkan persoalan nilai dengan persoalan dalam kehidupan, kepercayaan, dan perasaan mereka sendiri. Karena kepribadian siswa/pelajar terlibat maka pembelajaran menjadi lebih menarik (Zuchdi, 2004).

\section{Pengembangan keterampilan (Soft Skill)}

Siswa atau pelajar diharapkan dapat mengembangkan ketrampilan-ketrampilan untuk mengarahkan dalam kehidupan keseharian dan bisa mengatasi persoalan atau hambatan yang dialami dalam kehidupannya dalam masyarakat. Ada berbagai ketrampilan yang diperlukan agar seseorang dapat mengamalkan nilai-nilai yang dianut sehingga berperilaku konstruktif dan bermoral dalam masyarakat. Ketrampilan tersebut antara lain berpikir kritis, berpikir kreatif, berkomunikasi secara jelas, menyimak, bertindak asertif (terbuka), dan menemukan resolusi konflik, yang secara ringkas disebut ketrampilan akademik dan ketrampilan sosial.

Ciri-ciri orang yang berpikir kritis adalah sebagai berikut: (1) mencari kejelasan pernyataan atau pertanyaan; (2) mencari alas an; (3) mencoba memperoleh informasi yang benar; (4) menggunakan sumber yang dapat dipercaya; (5) mempertimbangkan keseluruhan situasi; (6) mencari alternatif; (7) bersikap terbuka; (8) mengubah pandangan apabila ada bukti yang dapat dipercaya; (9) mencari ketepatan suatu permasalahan; (10) sensitive terhadap perasaan, tingkat pengetahuan, dan tingkat kecanggihan orang lain (Zuchdi, 2004). Kesepuluh ciri tersebut hanya dapat dikembangkan lewat latihan yang dilakukan secara terus menerus sehingga akhirnya menjadi suatu kebiasaan. Berpikir kritis dapat mengarahkan pada pembentukan sifat bijaksana. Berpikir kritis dapat memungkinkan seseorang dapat menganalis informasi secara cermat dan membuat keputusan yang tepat dalam menghadapi isu-isu yang kontroversial. Dengan demikian, dapat dihindari tindakan destruktif sebagai akibat dari ulah provokator yang tidak henti-hentinya mencari korban. Oleh karena itu, sangat diharapkan peran guru dan orang tua untuk membiasakan anak-anak dan siswa berpikir kritis dengan memberikan kegiatan-kegiatan yang mengandung ciri-ciri tersebut di atas (Zuchdi, 2004).

Ketrampilan mengatasi masalah karena masih banyaknya orang yang mengatasi konflik dengan kekuatan fisik, padahal cara demikian itu biasa digunakan oleh binatang. Apabila kita menghendaki kehidupan berdasarkan nilai-nilai religious dan prinsip-prinsip moral, kita perlu mengajarkan cara-cara mengatasi konflik secara konstruktif. Para guru dan orangtua memang harus berusaha keras untuk menyakinkan 
anak-anak atau siswanya bahwa menyelesaikan masalah secara destruktif yang banyak muncul dalam masyarakat Indonesia saaat ini sangat tidak manusiawi dan bertentangan dengan norma-norma agama Islam yang harus kita junjung tinggi.

Pendidikan pendidikan karakter atau pendidikan nilai yang diajarkan dalam mata pelajaran Pendidikan Pancasilan dan Kewarganegaraan (PPKn) di SMA hendaknya dilakukan secara menyeluruh baik dalam proses pembelajaran di kelas. Pendidikan karakter dapat diselenggarakan di sekolah seperti kegiatan ekstrakurikuler, dalam proses bimbingan dan penyuluhan, dalam upacara bendera, upacara-upacara pemberian penghargaan dan dalam aspek kehidupan.

\section{SIMPULAN}

Pembelajaran Pendidikan Pancasila dan Kewarganegaraan (PPKn) bertujuan pembentukan karakter siswa atau pelajar dengan menggunakan pendekatan komprehenshif telah sesuai untuk diterapkan, karena masa sekarang ini kehidupan sudah semakin kompleks dan perubahan di segala kehidupan berlangsung dengan sangat cepat. Pendidikan nilai dan moral di Indonesia sudah cukup komprehensif, karena nilai-nilai fundamental yang dapat menuntun ke arah pencapaian kebahagian dunia dan akhirat untuk seluruh umat manusia telah disampaikan kepada siswa atau pelajar melalui mata pelajaran PPKn dan juga mata pelajaran agama, awalaupun dalam segi metode dan strateginya masih ada kelemahan yang perlu diatasi dan diberikan solusi ataupun jalan keluarnya agar tercapainya tujuan pendidikan nasional Indonesia. Dari hasil penelitian yang dilakukan peneliti pada 5 sekolah yang berada di wilayah Daerah Istimewa Yogyakarta dapat disimpulkan bahwa dalam pengembangan model pembelajaran PPKn berbasis karakter selama ini sudah menggunakan pendekatan komprehensif yaitu penanaman nilai (inkulkasi), pemodelan, fasilitasi dan pengembangan ketrampilan (soft skill).

\section{SARAN}

Pendekatan komprehensif dalam pembelajaran PPKn perlu ditingkatkan dengan menngunakan instrumen evaluasi yang baik. Karena evaluasi pendidikan nilai dan moral atau pendidikan karakter harus dapat menggambarkan secara akurat, baik pemikiran, penalaran moral, afek moral (hubungan dengan perasaan/hati nurani), maupun perilaku moral (moral action), maka perlu dikembangkan evaluasi untuk ketiga ranah tersebut. 


\section{UCAPAN TERIMAKASIH}

Terimakasih diucapkan kepada Kepala sekolah yang telah memberikan ijin penelitian serta guru dan karyawan SMA N 2 Sleman, SMA N 1 Sentolo Kulon Progo, SMA Negeri Patuk Gunung Kidul, SMA N 1 Banguntapan Bantul dan SMA Muhammadiyah 2 Yogyakarta yang telah bekerjasama dalam kelancaran penelitian ini. Semoga penelitian ini bisa bermanfaat guna pengembangan ilmu pengetahuan dan pengembangan keterampilan. Kami juga mengucapkan terima kasih kepada Direktorat Riset dan Pengabdian kepada Masyarakat, Direktorat Jenderal Pemberdayaan Penelitian dan Pengembangan Kementerian Riset Teknologi dan Pendidikan Tinggi (Direktorat Riset dan Pengabdian Masyarakat, Direktorat Jenderal Penguatan Riset dan Pengembangan Kementerian Riset, Teknologi, dan Pendidikan Tinggi Republik Indonesia) atas dukungan dana untuk penelitian dan publikasi artikel ini dengan nomor Hibah 081 / SP2HMAD / LT / DRPM / 2020.

\section{DAFTAR PUSTAKA}

Arthur, J., \& Harrison, T. (2012). Exploring good character and citizenship in England. Asia Pacific Journal of Education, 32(4), 489-497.

B.-Y. Sim, J., \& Low, E. L. (2012). Character and citizenship education: Conversations between personal and societal values. Asia Pacific Journal of Education, 32(4), 381394.

Berkowitz, M. W., \& Bier, M. C. (2004). based character education. The Annals of the American Academy of Political and Social Science, 591(1), 72-85.

Flanagan, O. J., Rorty, A. O., \& Rorty, A. (1993). Identity, character, and morality: Essays in moral psychology. MIT press.

Kusumawati, I. (2016). Landasan Filosofis Pengembangan Karakter Dalam Pembentukan Karakter. Academy of Education Journal, 7(1), 1-15. https://doi.org/10.47200/aoej.v7i1.342

Kusumawati, I., \& Zuchdi, D. (2019). Pendidikan Moral Anak Usia Dini Melalui Pendekatan Konstruktivis. Academy of Education Journal, 10(01), 63-75. https://doi.org/10.47200/aoej.v10i01.272

Lickona, T. (1991). Educating for character (New York, Bantam). McCI ET NAN, BE (1992) Schools and the Shaping of Character: Moral Education in America, 525543.

Lickona, T., \& Matters, C. (2012). How to help our children Develop Good Judgement, integrity, and other essensial Virtues. Terjemahan. Jakarta: PT. Bumi Aksara.

Noddings, N. (2002). Educating moral people: A caring alternative to character education. ERIC.

Nucci, L., \& Narváez, D. (2014). Handbook of moral and character education. Routledge. 
Sisdiknas, U.-U. (2003). Undang-Undang RI No. 20 Tahun 2003. Jakarta: Sinar Grafika.

Sumardjoko, B. dan M. M. (2003). Model Of Civic Education Learning Based On The Local Wisdom. 20.

Zuchdi, D. (2004). Humanisasi Pendidikan dan Pengembangan Keterampilan Mengatasi Konflik. Jurnal Cakrawala Pendidikan, 2(2). 